Tropical Journal of Pharmaceutical Research May 2019; 18 (5): 1083-1088

ISSN: $1596-5996$ (print); 1596-9827 (electronic)

(c) Pharmacotherapy Group, Faculty of Pharmacy, University of Benin, Benin City, 300001 Nigeria.

\title{
Antidepressant effect of methanol extract of smokeless tobacco and identification of its bioactive components
}

\author{
Siddig I Abdelwahab ${ }^{1 *}$, Syam Mohan ${ }^{2}$, Manal ME Taha ${ }^{2}$, Waquar Ahsan³, \\ Mohammed Al Bratty ${ }^{3}$, Hassan A Alhazmi ${ }^{1,3}$ \\ ${ }^{1}$ Substance Abuse Research Centre, ${ }^{2}$ Biomedical Research Unit, Medical Research Centre, ${ }^{3}$ Department of Pharmaceutical \\ Chemistry, College of Pharmacy, Jazan University, Jazan, Saudi Arabia
}

*For correspondence: Email: siddigabde/wahab.sarc@gmail.com; Tel: +966-506612390

\begin{abstract}
Purpose: To investigate the antidepressant effect of methanol extract of smokeless tobacco and identify its bioactive compounds.

Methods: Adult Wistar rats were randomly assigned to five groups of five rats each: normal control group, standard (reference) control group as well as 100, 200 and $500 \mathrm{mg} / \mathrm{kg}$ extract group. The extract, standard drug (imipramine) and normal saline were administered via the intraperitoneal (i.p.) route. The rats were subjected to forced swim test (FST) and tail suspension test (TST) to assess the antidepressant effect of methanol extract of smokeless tobacco. Gas chromatography-mass spectrometry (GC-MS) was used to identify the bioactive compounds of the extract.

Results: The oral $L D_{50}$ of the extract was $>2000 \mathrm{mg} / \mathrm{kg}$. Significant decrease in immobility time was observed after single administration of imipramine $(p<0.05)$. The extract significantly and dosedependently decreased the immobility time, but increased climbing and swimming times, when compared with normal control group $(p<0.05)$. The immobility time of stressed rats regardless of sex was significantly and dose-dependently lowered, relative to normal control group $(p<0.05)$. Four major compounds were identified in the extract: nicotine (45.88\%); 1,5-dimethyl-2-pyrrolidinone (23.00\%), $n$ hexadecanoic acid (11.31\%) and vitamin A aldehyde (9.38\%).

Conclusion: These results demonstrate that the methanol extract of smokeless tobacco possesses antidepressant and mood-elevating effects in rats. However, its use should be discouraged since it contains a number of hazardous and carcinogenic components such as $\mathrm{N}$-nitroso compounds and benzo(a)pyrene which are categorized as Class-I carcinogens.
\end{abstract}

Keywords: Smokeless tobacco, Extract, Rats, Antidepressant, Imipramine, Immobility

This is an Open Access article that uses a fund-ing model which does not charge readers or their institutions for access and distributed under the terms of the Creative Commons Attribution License (http://creativecommons.org/licenses/by/4.0) and the Budapest Open Access Initiative (http://www.budapestopenaccessinitiative.org/read), which permit unrestricted use, distribution, and reproduction in any medium, provided the original work is properly credited.

Tropical Journal of Pharmaceutical Research is indexed by Science Citation Index (SciSearch), Scopus, International Pharmaceutical Abstract, Chemical Abstracts, Embase, Index Copernicus, EBSCO, African Index Medicus, JournalSeek, Journal Citation Reports/Science Edition, Directory of Open Access Journals (DOAJ), African Journal Online, Bioline International, Open-J-Gate and Pharmacy Abstracts

\section{INTRODUCTION}

Smokeless tobacco, also known as chewing tobacco or snuff, is re-emerging as a popular form of tobacco among male adolescents, but very little is known about its deleterious effects on health [1]. Shammah is a traditional form of smokeless tobacco that is commonly used in Saudi Arabia, Yemen and Sudan [2]. It is known as tombak in Sudan, shammah in Saudi Arabia, suns in Sweden and maras in Turkey [3]. The 
use of smokeless tobacco has not been legalized in many countries, and as a result, the actual amount consumed globally is difficult to estimate $[4,5]$. Adolescents and young adult males constitute the largest group of smokeless tobacco users [6]. Social pressure and use of psychoactive substances such as drugs, cigarettes, and alcohol are positively associated with the use of smokeless tobacco. Smokeless tobacco products are the main sources of tumorigenic nitrosamines, which are linked to increased risk of oral and pancreatic malignancies. A strong correlation exist between the use of smokeless tobacco and incidence of oral cancer, and smokeless tobacco users have high chances of developing cardiovascular diseases (CVDs), when compared with nonusers [7].

In addition to the established adverse effects of smokeless tobacco, mood elevation is another remarkable effect elicited by it, and nicotine is believed to play a role. Transdermal nicotine patches have been reported to improve mood and increase the duration of rapid eye movement (REM) sleep when used by non-smoking patients suffering from depression [8, 9]. Cessation of smoking leads to depression of central nervous system (CNS) and antidepressant therapy is needed to ameliorate such condition [10]. The antidepressant effect of nicotine in rats has been reported [11]. Most of the knowledge about the effect of smokeless tobacco on mood elevation is based on individual reports obtained from users. People often use smokeless tobacco products for mood elevation in order to cope with depression. As a result, they become dependent on the drug.

The aim of this study was to investigate the antidepressant effect of methanol extract of smokeless tobacco, and identify its bioactive compounds.

\section{EXPERIMENTAL}

\section{Tobacco samples and extraction}

Smokeless tobacco powder was obtained from an exclusive supplier in Jazan province of Saudi Arabia, and identified at Substance Abuse Research Centre, Jazan University. A portion of the powder $(500 \mathrm{~g})$ was weighed and extracted with $600 \mathrm{ml}$ absolute methanol thrice, and the resultant extracts were combined and filtered using Whatman ${ }^{\circledR}$ No. 41 filter paper $(20-25 \mu \mathrm{m})$ followed by MILLEX filter of $0.22 \mu \mathrm{m}$ pore size. The filtrate was concentrated using a vacuum rotary evaporator and refrigerated at $4{ }^{\circ} \mathrm{C}$ for later use.

\section{Experimental rats}

Adult Wistar rats of either sex, weighing between 150 and $200 \mathrm{~g}$ and aged 6 - 8 weeks were obtained from Central Experimental Animal House (CEAH) of Jazan University and used for this study. The rats were housed in iron cages under optimum conditions: $12 \mathrm{~h}$ day/12 $\mathrm{h}$ night cycle, $25^{\circ} \mathrm{C}$ and $40-60 \%$ humidity. They were allowed free access to standard rat feed and clean water. The study protocol was reviewed and approved by the Institutional Research Ethics Committee of Jazan University, Jazan (approval no. SARC.EC.80). Guidelines for the proper use and care of animals as prepared by the National Academy of Sciences, National Institute of Health were followed to provide humane care to all the rats [12].

\section{Acute toxicity study}

Acute oral toxicity of the methanol extract of smokeless tobacco was investigated using the revised Organization for Economic Co-operation and Development (OECD) guidelines [13]. The rats were administered graded doses of the extract and examined daily at intervals of $5 \mathrm{~h}$ for behavioral and clinical alterations for fourteen days.

\section{Forced swim test (FST)}

This was performed using standard method [14]. The rats were placed individually in a transparent Pyrex cylinder filled with water to a depth of 20 $\mathrm{cm}$. Familiarization and training were conducted two days prior to the commencement of the experiment. Following each swimming session, rats were taken out from water, dried using towel and placed back in their respective cages. Doses of the extract (100 - $500 \mathrm{mg} / \mathrm{kg}$ bwt), standard drug (15 mg/kg bwt imipramine), and $5 \mathrm{ml} / \mathrm{kg}$ bwt normal saline were administered intraperitoneally to the various groups $30 \mathrm{~min}$ before commencement of the test. Behaviors such as swimming, climbing and immobility were recorded within $5 \mathrm{~min}$. An augmentation in the time spent in swimming and climbing, with a reduction in immobility time were the behavioral responses considered as antidepressant effects [14].

\section{Tail suspension test (TST)}

Male and female rats $(n=25)$ were randomly assigned to five groups of five rats each. The normal control group received only normal saline (5 ml/kg bwt, i.p.). The three treatment groups received graded doses of methanol extract of smokeless tobacco (100 - $500 \mathrm{mg} / \mathrm{kg}$ bwt, i.p), 
while the standard control group received 15 $\mathrm{mg} / \mathrm{kg}$ bwt imipramine, i.p. The intervals of tail suspension, stress-induced immobility were recorded based on standard methods [14]. In this process, visually and acoustically isolated rats were hung $50 \mathrm{~cm}$ above the ground using adhesive tape at approximately $1 \mathrm{~cm}$ from the tail tip. Immobility of the rats was assumed only when they kept hanging passively without moving.

\section{GC-MS}

This was carried out using Trace 1301 Ultra Gas Chromatography machine fitted with a ZB-1 MS fused silica TR-5MS capillary column (size: $30 \mathrm{~m}$, inner diameter: $0.25 \mathrm{~mm}, \mathrm{D}_{\mathrm{f}}:: 0.25 \mu$ ). Electron ionization system with ionization energy of $70 \mathrm{eV}$ was utilized for MS detection. The carrier gas, helium was used at a constant flow rate of 1.1 $\mathrm{ml} / \mathrm{min}$. The injector line temperature was set at $250{ }^{\circ} \mathrm{C}$, while the MS transfer line temperature was set at $320^{\circ} \mathrm{C}$. The oven was heated from 60 - $250{ }^{\circ} \mathrm{C}$ with an increase of $3{ }^{\circ} \mathrm{C}$ per min, held isothermally at $250{ }^{\circ} \mathrm{C}$ for $10 \mathrm{~min}$, and then increased to $320^{\circ} \mathrm{C}$ at a ramp rate of $10{ }^{\circ} \mathrm{C}$ per min. The methanol extract of smokeless tobacco was first diluted with methanol $(1: 100, v / v)$ and injected into the system using autosampler A1/AS 3000 working in the splitless mode. The mean peak area for any component was divided by total area and multiplied with one hundred to give the percentage abundance of each component, while X-Calibur software was used to analyze all chromatograms and mass spectra.

\section{Statistical analysis}

Data are expressed as mean \pm SEM, and statistical analysis was performed using SPSS, version 20.0. Groups were compared using Duncan multiple test range. Values of $p<0.05$ were considered statistically significant.

\section{RESULTS}

\section{Oral $L_{50}$ of methanol extract of smokeless tobacco}

Methanol extract of smokeless tobacco did not elicit any behavioral changes and mortality when administered up to $2000 \mathrm{mg} / \mathrm{kg}$ bwt. The oral $\mathrm{LD}_{50}$ of the extract was therefore taken to be > $2000 \mathrm{mg} / \mathrm{kg}$ bwt (Table 1).

\section{Outcome of FST}

A significant decrease in immobility time was observed after single administration of imipramine $(p<0.05)$. The methanol extract significantly and dose-dependently decreased the immobility time, and significantly increased the climbing and swimming time, when compared with the normal control group ( $p<0.05$; Table 2$)$.

\section{Outcome of TST}

As shown in Figure 1, the methanol extract significantly and dose-dependently decreased the immobility time of stressed rats regardless of sex, relative to the normal control group ( $p<$ 0.05). Immobility time was also significantly reduced by imipramine at a dose of $15 \mathrm{mg} / \mathrm{kg}$ bwt $(p<0.05)$.

Table 1: Acute toxicity of methanol extract of smokeless tobacco

\begin{tabular}{lcccc}
\hline $\begin{array}{l}\text { Dose } \\
\text { (mg/kg } \\
\text { bwt) }\end{array}$ & $\begin{array}{c}\text { Number } \\
\text { of rats }\end{array}$ & Mortality & Survival & $\begin{array}{c}\text { Mortality } \\
\text { ratio }\end{array}$ \\
\hline 10 & 3 & 0 & 3 & $0 / 3$ \\
100 & 3 & 0 & 3 & $0 / 3$ \\
1000 & 3 & 0 & 3 & $0 / 3$ \\
1500 & 1 & 0 & 1 & $0 / 1$ \\
2000 & 1 & 0 & 1 & $0 / 1$ \\
\hline
\end{tabular}

Table 2: Effect of methanol extract of smokeless tobacco on immobility, climbing and swimming time in FST

\begin{tabular}{|c|c|c|c|c|c|c|}
\hline \multirow[t]{2}{*}{ Group } & \multicolumn{2}{|c|}{ Immobility time (s) } & \multicolumn{2}{|c|}{ Climbing time (s) } & \multicolumn{2}{|c|}{ Swimming time (s) } \\
\hline & Male & Female & Male & Female & Male & Female \\
\hline Standard control & $\begin{array}{c}60.57 \pm \\
2.80^{\star *}\end{array}$ & $67.83 \pm 1.2^{* *}$ & $\begin{array}{c}151.78 \pm \\
0.59^{\star *}\end{array}$ & $\begin{array}{c}157.85 \pm \\
1.5^{\star \star}\end{array}$ & $\begin{array}{c}68.2 \pm \\
1.4^{\star *}\end{array}$ & $\begin{array}{l}70.4 \pm \\
0.49^{\star *}\end{array}$ \\
\hline $100 \mathrm{mg} / \mathrm{kg}$ extract & $\begin{array}{c}82.45 \pm \\
3.10^{*}\end{array}$ & $\begin{array}{c}86.57 \pm \\
0.97^{*}\end{array}$ & $53.20 \pm 1.41^{*}$ & $56.93 \pm 4.5^{\star}$ & $\begin{array}{l}57.1 \pm \\
0.59^{\star}\end{array}$ & $60.1 \pm 0.55^{\star}$ \\
\hline $200 \mathrm{mg} / \mathrm{kg}$ extract & $\begin{array}{c}62.19 \pm \\
0.98^{*}\end{array}$ & $\begin{array}{c}74.62 \pm \\
0.48^{*}\end{array}$ & $120.55 \pm 1.56^{*}$ & $\begin{array}{c}107.46 \pm \\
0.89^{*}\end{array}$ & $\begin{array}{l}58.2 \pm \\
0.27^{\star}\end{array}$ & $59.0 \pm 1.5^{*}$ \\
\hline $500 \mathrm{mg} / \mathrm{kg}$ extract & $\begin{array}{l}46.47 \pm \\
2.40^{\star \star \star}\end{array}$ & $\begin{array}{c}49.72 \pm \\
1.41^{\star *}\end{array}$ & $\begin{array}{c}145.90 \pm \\
0.97^{\star *}\end{array}$ & $\begin{array}{c}139.45 \pm \\
0.72^{* \star}\end{array}$ & $\begin{array}{l}67.4 \pm \\
0.49^{\star \star}\end{array}$ & $\begin{array}{l}69.1 \pm \\
0.56^{\star \star}\end{array}$ \\
\hline Normal control & $\begin{array}{c}140.33 \pm \\
5.70\end{array}$ & $\begin{array}{c}145.94 \pm \\
2.71\end{array}$ & $33.98 \pm 0.65$ & $35.10 \pm 5.92$ & $\begin{array}{c}32.47 \pm \\
0.73\end{array}$ & $\begin{array}{c}30.5 \pm \\
2.8\end{array}$ \\
\hline
\end{tabular}

${ }^{\star} P<0.05,{ }^{* \star} p<0.01,{ }^{\star \star *} p<0.001$, when compared with normal control group 


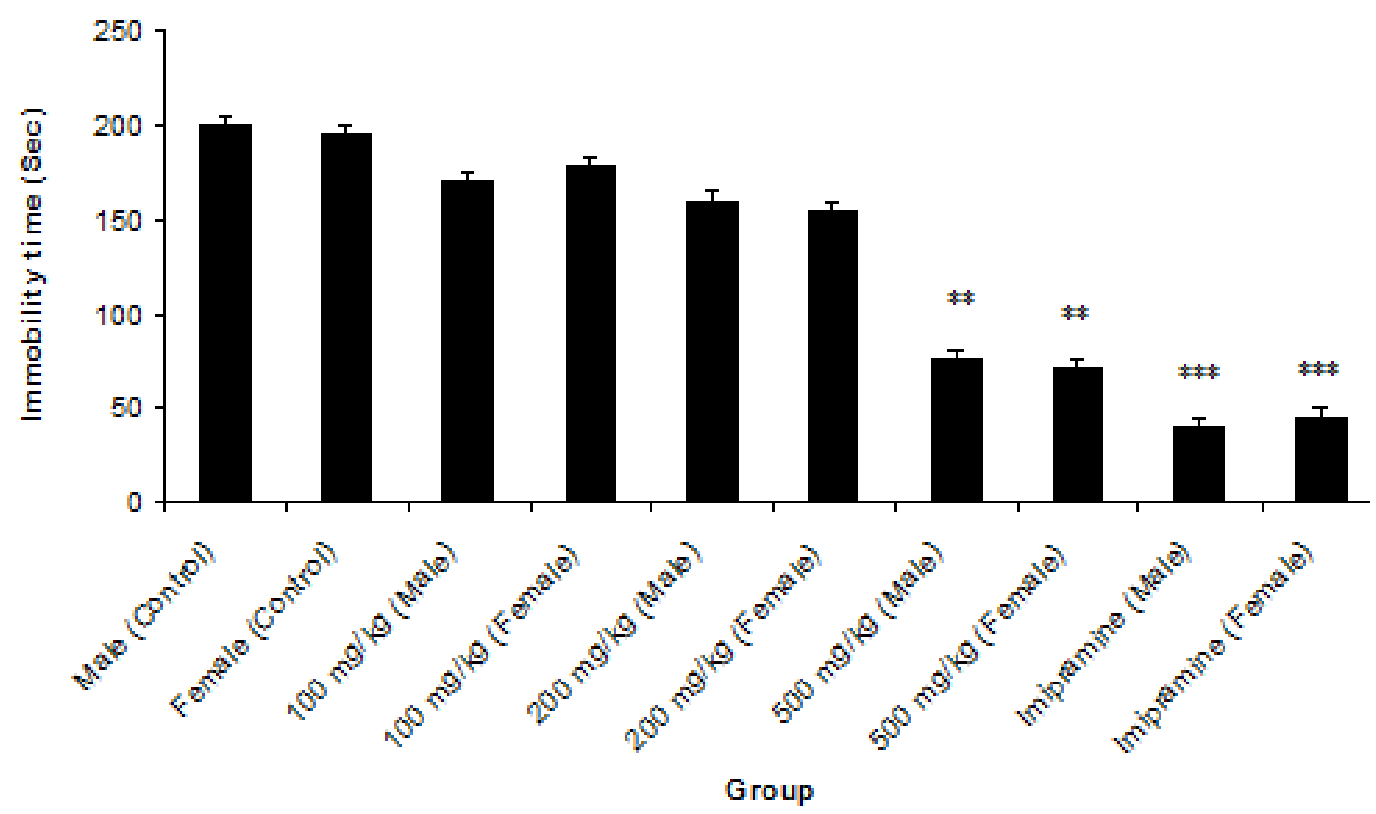

Figure 1: Anti-depressant properties of methanol extract of smokeless tobacco as revealed by TST. ${ }^{*} P<0.05 \&$ ${ }^{* * *} p<0.01$, when compared with the normal control group

\section{Bioactive compounds methanol extract of smokeless tobacco}

Four major components were identified in the methanol extract of smokeless tobacco: nicotine (45.88 \%), 1, 5-dimethyl-2-pyrrolidinone (23.00 $\%), n$-hexadecanoic acid (11.31\%) and vitamin A aldehyde $(9.38 \%)$. Four minor constituents were also identified. These were ricinoleic acid $(4.41 \%) \quad n$-tridecan-1-ol (2.87 \%), 11hydroxypregn-4-ene-3, 20-dione (2.10\%), and trimethyl [3,7,7-bicyclo(4.1.0) hept-2-ene] (1.45 $\%)$. These results are shown in Table 3.

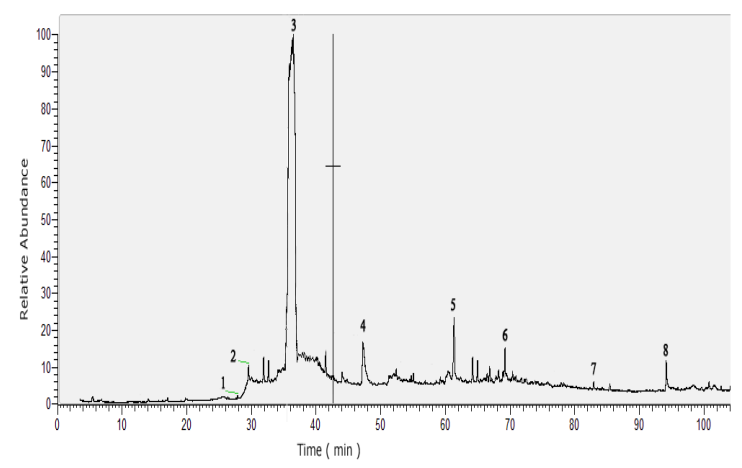

Figure 2: Total ionic chromatogram (GC-MS) of methanol extract of smokeless tobacco

\section{DISCUSSION}

The present study evaluated the antidepressant or mood elevating effect of smokeless tobacco in vivo, and it was designed on the premise that cigarette or smoked tobacco is used by some persons to reduce stress. The mood-elevating effect of smokeless tobacco is largely based on the experiences shared by its users, since no scientific data has been reported so far on it. Nicotine has been shown to exert some beneficial effects on stress and depression in both animals and humans [11]. It has been proposed that nicotinic acetylcholine receptors modify the pathways associated with stress response, depression and anxiety in a normal brain, and that smoking results in modulations of mood and anxiety levels $[15,16]$.

At present, FST and TST are the most widely used models of stress in rodents, based on different pathophysiological mechanisms. Biomedical studies suggest that dopamine is essential for responsiveness of animals in the FST, but in TST animal model, both dopaminergic and serotonergic systems are involved [14,17]. In this study, the methanol extract of smokeless tobacco significantly and dose-dependently decreased immobility time and significantly increased the climbing and swimming time, when compared with the normal control group. During FST, the behavior exhibited by rats administered the methanol extract was similar to that of imipramine, an indication that the extract may act via augmentation of norepinephrine neurotransmission [18]. Acute dosing of majority of antidepressants reduces immobility time in TST model. The immobility displayed by experimental rats in these models is a measure of behavioral despair which is synonymous with depression $[19,20]$. These results suggest that nicotine possesses 
Table 3: GC-MS profile of methanol extract of smokeless tobacco

\begin{tabular}{lccl}
\hline S/N & $\begin{array}{r}\text { Retention time } \\
(\mathbf{m i n})\end{array}$ & Peak area (\%) & Identity \\
\hline 1 & 27.87 & 1.45 & Bicyclo(4.1.0)hept-2-ene,3,7,7-trimethyl \\
2 & 29.56 & 2.87 & $n$-Tridecan-1-ol \\
3 & 36.44 & 45.88 & Nicotine \\
4 & 47.24 & 23.00 & 1,5 -Dimethyl-2-pyrrolidinone \\
5 & 61.36 & 11.31 & n-Hexadecanoic acid \\
6 & 69.20 & 9.38 & Vitamin A aldehyde \\
7 & 82.92 & 2.10 & Pregn-4-ene-3,20-dion,11-hydroxy \\
8 & 94.14 & 4.41 & Ricinoleic acid \\
\hline
\end{tabular}

antidepressant and mood-elevating properties, since nicotine was identified as one of the major bioactive compound in the extract.

Several studies have supported the speculation that nicotine is responsible for the antidepressant activity of tobacco. Smokeless tobacco generally has more nicotine content that smoked tobacco, since it is unprocessed in most cases. Shammah, which is manufactured locally in Saudi Arabia, is usually adulterated to enhance its organoleptic and mood elevating properties.

\section{CONCLUSION}

The results of this study have shown that methanol extract of smokeless tobacco possesses antidepressant and mood-elevating effects in rats. However, its use should be discouraged since it contains a number of hazardous and carcinogenic components such as $N$-nitroso compounds and benzo(a)pyrene which are Class-I carcinogens.

\section{DECLARATIONS}

\section{Acknowledgement}

This work was supported with a grant from the Deanship of Scientific Research, Jazan University, Jazan, Saudi Arabia (no. RG-2-9).

\section{Conflict of interest}

No conflict of interest is associated with this work.

\section{Contribution of authors}

This work was done by the author(s) named in this article and all liabilities pertaining to claims and contents will be borne by the authors. Siddig I Abdelwahab carried out the experimental design, performed data analysis and wrote the manuscript. Syam Mohan, Manal ME Taha, and Mohammad Al Bratty assisted in carrying out the experimental design and data analysis. Waquar Ahsan wrote and proofread the manuscript, while Hassan A Alhazmi was involved in the conceptualization and design of the study. All the authors read and approved the manuscript for publication.

\section{Open Access}

This is an Open Access article that uses a funding model which does not charge readers or their institutions for access and distributed under the terms of the Creative Commons Attribution License (http://creativecommons.org/licenses/by/ 4.0) and the Budapest Open Access Initiative (http://www.budapestopenaccessinitiative.org/rea d), which permit unrestricted use, distribution, and reproduction in any medium, provided the original work is properly credited.

\section{REFERENCES}

1. Jamal A, Gentzke A, Hu SS, Cullen KA, Apelberg BJ, Homa DM, King BA. Tobacco use among middle and high school students-United States, 2011 - 2016. Morbid Mortal Weekly Rep. 2017; 66: 597.

2. Keith $H$, Kathryn $O$, Priya $K$, Rashidah W. Oral and systemic effects of smokeless tobacco from the African, Asian, Latin American, European, and Middle Eastern Regions. J. Dent. Oral Health. 2017; 6: 2.

3. International Agency for Research on Cancer. Smokeless tobacco and some tobacco-specific $\mathrm{N}$-nitrosamines, Vol. 89, Lyon, France; 2007. pp. 15 - 20.

4. Alsanosy RM. Smokeless tobacco (shammah) in Saudi Arabia: a review of its pattern of use, prevalence, and potential role in oral cancer. Asian Pac. J. Cancer Prev. 2014; 15: 6477 - 6483.

5. Boffetta $P$, Hecht $S$, Gray $N$, Gupta $P$, Straif $K$. Smokeless tobacco and cancer. Lancet Oncol. 2008; 9: $667-675$.

6. Al-Tayar B, Tin-Oo MM, Sinor MZ, Alakhali MS. Prevalence and association of smokeless tobacco use with the development of periodontal pocket among adult males in Dawan Valley, Yemen: a cross-sectional study. Tob Induc. Dis. 2015; 13: 35. 
7. Rao SVK, Mejia G, Roberts-Thomson $K$, Logan $R$. Epidemiology of oral cancer in Asia in the past decadean update (2000 - 2012). Asian Pac. J. Canc. Prev. 2013; 14: 5567 - 5577.

8. Salín-Pascual RJ, Drucker-Colín R. A novel effect of nicotine on mood and sleep in major depression. Neuroreport. 1998; 9: 57 - 60.

9. Salín-Pascual RJ, Rosas M, Jimenez-Genchi A, RiveraMeza BL, Delgado-Parra V. Antidepressant effect of transdermal nicotine patches in nonsmoking patients with major depression. J. Clin. Psych. 1996; 57: 387. 389.

10. Hall SM, Reus VI, Munoz RF, Sees KL, Humfleet G, Hartz DT, Frederick S, Triffleman E. Nortriptyline and cognitive-behavioral therapy in the treatment of cigarette smoking. Arch. Gen. Psych. 1998; 55: 683 - 690.

11. Vieyra-Reyes $P$, Venebra-Muñoz A, Rivas-Santiago $B$, García-García F. Nicotine as an antidepressant and regulator of sleep in subjects with depression. Rev. Neurol. 2009; 49: 661 - 667.

12. National Research Council. Guide for the Care and Use of Laboratory Animals. Washington, DC. 8th ed. The National Academies Press; 2011. pp. 26.

13. Hund-Rinke K, Baun A, Cupi D, Fernandes TF, Handy R, Kinross JH, Navas JM, Peijnenburg W, Schlich K, Shaw $B J$. Regulatory ecotoxicity testing of nanomaterialsproposed modifications of OECD test guidelines based on laboratory experience with silver and titanium dioxide nanoparticles. Nanotoxicol. 2016; 10: 1442 - 1447.
14. Nöldner $M$, Schötz $K$. Rutin is essential for the antidepressant activity of Hypericum perforatum extracts in the forced swimming test. Planta Med. 2002; 68: 577 580.

15. Wong $A H$, Smith $M$, Boon HS. Herbal remedies in psychiatric practice. Arch. Gen. Psych. 1998; 55: 1033 1044.

16. Papke RL, Dwoskin LP, Crooks PA. The pharmacological activity of nicotine and nornicotine on nAChRs subtypes: relevance to nicotine dependence and drug discovery. J. Neurochem. 2007; 101: 160 - 167.

17. Picciotto MR, Brunzell DH, Caldarone BJ. Effect of nicotine and nicotinic receptors on anxiety and depression. Neuroreport. 2002; 13: 1097 - 1106.

18. Cryan JF, Mombereau C, Vassout A. The tail suspension test as a model for assessing antidepressant activity: review of pharmacological and genetic studies in mice. Neurosc. Biobehav. Rev. 2005; 29: 571 - 625.

19. Valdes-Sustaita B, Lopez-Rubalcava C, GonzalezTrujano ME, Garcia-Viguera C, Estrada-Camarena E. Aqueous extract of pomegranate alone or in combination with citalopram produces antidepressantlike effects in an animal model of menopause: participation of estrogen receptors. Int. J. Mol. Sci. 2017; 18: 2643.

20. Shalam M, Shantakumar S, Narasu ML. Pharmacological and biochemical evidence for the antidepressant effect of the herbal preparation Trans-01. Ind. J. Pharmacol. 2007; 39: 231. 